activity may also cause them to adopt other means of maintaining good health.

We recognize that the assessment of physical activity in this study was subjective, but we made a special attempt to distinguish those men performing minimum and heavy activity. Our findings suggest that if habitual heavy leisure activity is associated with reduced morbidity from coronary heart disease, as reported by Morris et al., ${ }^{8}$ the mechanism may be through an associated lower level of coronary risk factors. Further study is required to determine possible social, biological, or psychological differences that may exist among young and middle-aged men who enjoy different levels of physical activity during their leisure time.

We thank Gilbert MacKenzie, department of social and preventive medicine, Queen's University, Belfast, and Julian McAirt, department of statistics, Trinity College, Dublin, for their advice and help.

\section{References}

${ }^{1}$ Shapiro, S., et al., fournal of Chronic Diseases, 1965, 18, 527.

2 Morris, J. N., et al., Lancet, 1966, 2, 553.

${ }^{3}$ Kannel, W. B., Sorlie, P., and McNamara, P., Coronary Heart Disease and Physical Fitness, ed. D. A. Larsen and R. D. Malmborg, p. 256. Copenhagen, Munksgaard, 1971.

${ }^{4}$ Stamler, J., et al., fournal of Chronic Diseases, 1960, 11, 405.

5 Paul, O., et al., Circulation, 1963, 28, 20.

6 Taylor, H. L. H., et al., Circulation, 1970, Suppl. 1, p. 211.

' Karvonen, M. J., et al., Circulation, 1970, Suppl. 1, p. 52.

${ }^{8}$ Morris, J., et al., Lancet, 1973, 1, 333.

${ }^{9}$ Dahl, L. K., Niw England fournal of Medicine, 1958, 258, 1152.

${ }^{10}$ Holloszy, J. O., et al., American fournal of Cardiology, 1964, 14, 753.

${ }^{11}$ Mann, G. V., et al., American fournal of Medicine, 1969, 12, 46.

12 Paffenbarger, R. S., et al., New England Fournal of Medicine, 1970, 282, 1109.

${ }^{13}$ Taylor, H. L., Biskirk, E. R., and Remington, R. D., Federation Proceedings, 1973, 32, 1623.

${ }^{14}$ Hickey, N., et al., fournal of the Irish Medical Association, 1971, 64, 155.

${ }^{15}$ Moriarty, J., Computer Bulletin, 1970, 14, 7.

${ }^{16}$ Goodman, L. A., Fournal of the American Statistical Association, 1964, 59, 319.

\title{
Thalassaemia, Iron, and Pregnancy
}

\author{
U. M. HEGDE, S. KHUNDA, G. W. MARSH, G. H. HART, J. M. WHITE
}

British Medical fournal, 1975, 3, 509-511

\section{Summary}

Haematological values of 35 pregnant women with $\beta$-thalassaemia trait were followed during pregnancy. The discriminant function, calculated from haematological indices, was of no value in diagnosing $\beta$-thalassaemia trait during pregnancy. Initially patients were given iron supplements only if the serum iron and total iron binding capacity levels indicated iron deficiency, but bone marrow biopsies performed in the first 22 patients at 32 weeks indicated deficient iron stores. These patients were therefore given iron irrespective of their serum iron level. All subsequent patients with $\beta$-thalassaemia were also put on iron routinely at booking. Retrospectively the patients were divided into two groups. Patients in group 1 (18 patients) had received iron for less than 12 weeks, and their haemoglobin levels fell significantly during pregnancy $(P<0.001)$. Haemoglobin levels in 16 patients who had received iron for more than 12 weeks (group 2), however, did not fall significantly during pregnancy $(P<0.6)$. It is suggested (contrary to common practice) that patients with $\beta$-thalassaemia trait should be given iron supplements during pregnancy. Serum folate and vitamin $B_{12}$ levels did not change significantly in these patients and there was no increase in the incidence of maternal or fetal complications.

\section{North Middlesex Hospital, London N.18}

U. M. HEGDE, M.B., M.R.C.PATH., Senior Registrar in Haematology (Now at Hammersmith Hospital, London W12 0HS)

S. KHUNDA, F.R.C.S., M.R.C.o.G., Registrar in Obstetrics and Gynaecology (Now at Medical City, Baghdad, Iraq)

G. W. MARSH, M.D., M.R.C.PATH., Consultant Haematologist

G. H. HART, F.I.M.L.T., Chief Technician in Haematology

Royal Postgraduate Medical School and Hammersmith Hospital, London W12 0HS

J. M. WHITE, M.D., M.R.C.PATH., Lecturer in Haematology and Honorary Consultant Haematologist

\section{Introduction}

Patients suffering from $\beta$-thalassaemia trait have only mild, if any, anaemia. But at times of stress, especially pregnancy, they may develop moderate to severe anaemia. Generally doctors have been reluctant to prescribe iron supplements in pregnancy, though iron deficiency does occur in this condition. ${ }^{12}$ During a study of the haematological values of 35 pregnant women with $\beta$-thalassaemia trait we found that at 32 weeks of pregnancy, when bone marrow biopsies were performed in 22 women, 21 women were iron deficient; iron stores were absent and the sideroblast count was less than $10 \%$. Because of this finding all subsequent patients suffering from $\beta$-thalassaemia trait were given iron supplements from the time of booking. Retrospectively we examined the effect of adequate iron supplementation on the haemoglobin level. ${ }^{3}$

\section{Patients and Methods}

Thirty-five patients were studied. All came from a "high-risk" group of Middle-eastern or Mediterranean origin. $\beta$-Thalassaemia trait was diagnosed by the investigations described below.

Methods.-Routine haematological methods used were those described by Dacie and Lewis. ${ }^{3}$ The haemoglobin $\mathrm{A}_{2}$ level was quantified according to the method of Marengo-Rowe. ${ }^{4}$ Levels above 3.5 were considered diagnostic of $\beta$-thalassaemia trait. Haemoglobin $\mathrm{F}$ was quantified by alkaline denaturation. ${ }^{5}$ Haematological indices were measured at fortnightly intervals on a Coulter Model S counter. The discriminant function (= mean cell volume - red blood count (haemoglobin $\times 5$ ) -3.4 ) of England and Fraser ${ }^{6}$ used to distinguish $\beta$-thalassaemia trait from iron deficiency was calculated at antenatal booking, at the 30th week, and in the first week post hartum. Serum iron and total iron binding capacity (T.I.B.C.) were measured each month. Goldberg and Schwartz ${ }^{7}$ have reported increased folate demands in women with $\beta$-thalassaemia trait during pregnancy, so serum folate and vitamin $B_{12}$ levels were also measured each month. Bone marrow biopsies were carried out at the 32nd week of pregnancy. The aspirations were studied for evidence of megaloblastic erythropoiesis, and cell morphology and reticulo-endothelial iron stores and erythron iron were assessed independently by two people.

\section{Results}

In 35 women with the $\beta$-thalassaemia trait mean values at first antenatal presentation were haemoglobin $10.9 \mathrm{~g} / \mathrm{dl}$, mean cell volume 
$65 \mathrm{fl}$, mean cell haemoglobin $29 \mathrm{pg}$, and $\mathrm{Hb} \mathrm{A}_{2} 4 \cdot 2 \%$. Serum iron and T.I.B.C. levels showed wide variations. The variation was also great when measured each month. At 32 weeks when bone marrow biopsies were carried out on 22 patients 21 were found to have absent iron stores and sideroblast counts of less than $10 \%$. Only seven of these patients had serum iron levels of less than $13.4 \mu \mathrm{mol} / 1(75 \mu \mathrm{g} / 100 \mathrm{ml})$, and $10 \mathrm{had}$ T.I.B.C. levels of over $89.5 \mu \mathrm{mol} / 1(500 \mu \mathrm{g} / 100 \mathrm{ml})$, measured at the time of bone marrow aspiration (see table). Because we felt that serum iron and T.I.B.C. levels were not reliable indices of incipient iron deficiency all subsequent patients were put on iron supplements. The differences in the haemoglobin levels at antenatal booking and third trimester between those patients who had received iron for less than 12 weeks (group 1 ) and those who had received it for more than 12 weeks (group 2) are shown in fig. 1. The mean initial haemoglobin values were similar in both groups-11.1 $\mathrm{g} / \mathrm{dl}$ and $10.8 \mathrm{~g} / \mathrm{dl}$, respectively - but in group 1 this fell to a mean of $9.6 \mathrm{~g} / \mathrm{dl}(\mathrm{P}<0.001)$ while in group 2 there was no fall $(10.7 \mathrm{~g} / \mathrm{dl}$; $\mathrm{P}<0 \cdot 6)$. One patient who had mild megaloblastic bone marrow changes was excluded.

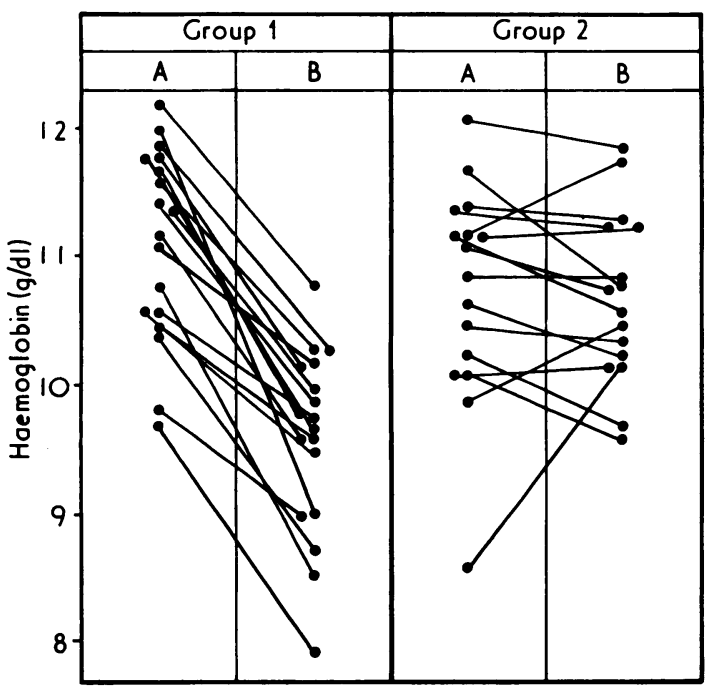

FIG. 1-Effects of therapeutic iron on haemoglobin levels during pregnancy in patients who had iron for less than 12 weeks (group 1) and in those who had iron for more than 12 weeks (group 2). $A=$ Haemoglobin at antenatal booking. $\mathrm{B}=$ Lowest haemoglobin value in third trimester.

The values obtained for the discriminant function are shown in fig. 2. Normally patients with iron deficiency anaemia have a positive discriminant function and those with $\beta$-thalassaemia trait a negative function. Nineteen of our patients $(54 \%)$ at booking, however, and 30 $(86 \%)$ at the 30th week had a positive value, and on the fourth day after delivery 28 patients $(80 \%)$ still retained this positive value.

There was no significant change in serum $B_{12}$ levels during pregnancy. The serum folate fell to subnormal levels in only one patient, who showed mild megaloblastic change on bone marrow examination at the 32nd week (this patient was excluded from analysis). There was no increase in obstetric or fetal complications in either group compared with normal women.

\section{Discussion}

Our results confirm the view of England and Fraser ${ }^{6}$ that the discriminant function has no validity in differentiating $\beta$ -

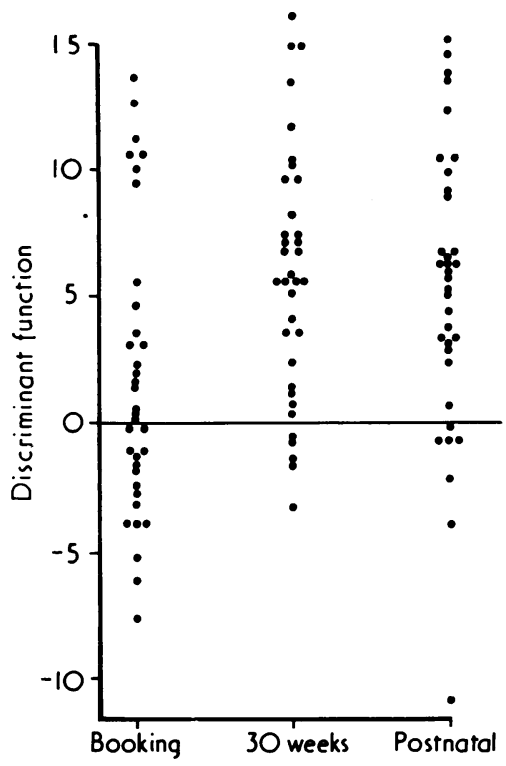

FIG. 2-Distribution of discriminant function derived from mean cell volume, red blood count, and haemoglobin concentration (discriminant function $=$ M.C.V. - R.B.C. $-(\mathrm{Hb} \times 5)-3 \cdot 4)$ in pregnancy and in the first week after delivery.

thalassaemia minor from iron deficiency during pregnancy. It was of interest that the discriminant function should retain its positive value in 28 patients on the fourth day after delivery, by which time the haemodilution that occurs in pregnancy should normally have corrected.

Doctors are reluctant to give iron supplements to pregnant women with $\beta$-thalassaemia trait, but our results indicate that if iron is given for an adequate period there is little change in the mean haemoglobin level of these patients. These results must be regarded as preliminary because of the nature of the study. It was completely fortuitous that the beneficial effect of iron on the haemoglobin level was discovered, and, obviously, a larger double-blind trial is required before we can be certain that iron treatment is valuable. Our results might also be criticized because of the division of the groups on the basis of whether iron was given for more than 12 weeks or not. Twelve weeks was chosen since this is an acceptable period of time to replete deficient body stores. Overall, however, we believe that our data are sufficient to indicate that all women with $\beta$ thalassaemia should be given iron. Moreover, serum iron and T.I.B.C. values are of little value in assessing iron stores in pregnancy in that there is no correlation between the stores and the indices.

The cause of the anaemia during pregnancy in these patients has been widely discussed, ${ }^{1}{ }^{2} 8$ but some confusion remains as regards its management. Schuman et al. ${ }^{\circ}$ showed that the red cell mass in pregnant women with thalassaemia trait increased but not to the same extent as that in normal women. Haemodilution alone, however, may not explain the degree of anaemia that is sometimes seen. These authors ${ }^{\circ}$ also suggested that hormonal influences could possibly alter the rates of globin chain synthesis during pregnancy and that an increased rate of $\gamma$-chain synthesis could bind some of the excess $\alpha$-chains,

Serum Iron and Total Iron Binding Capacity Levels during Pregnancy in Women with $\beta$-Thalassaemia Trait

\begin{tabular}{|c|c|c|c|c|c|c|c|c|c|c|c|}
\hline & & & & & \multirow{2}{*}{$\begin{array}{c}\text { No. of } \\
\text { Estimations }\end{array}$} & \multicolumn{3}{|c|}{ Serum Iron $(\mu \mathrm{mol} / \mathrm{l})$} & \multicolumn{3}{|c|}{ T.I.B.C. $(\mu \mathrm{mol} / \mathrm{l})$} \\
\hline & & & & & & Range & Mean & $\begin{array}{c}\text { No. }(\%) \\
<75 \mu \mathrm{g} \\
(<13.4 \mu \mathrm{mol})\end{array}$ & Range & Mean & $\begin{array}{c}\text { No. }(\%) \\
>500 \mu \mathrm{g} \\
(>89.5 \mu \mathrm{mol})\end{array}$ \\
\hline $\begin{array}{l}\text { Total .. } \\
\text { At antenatal booking } \\
\text { At bone marrow aspiration }\end{array}$ & $\begin{array}{l}\cdots \\
\cdots\end{array}$ & $\begin{array}{l}\cdots \\
\cdots \\
\cdots\end{array}$ & $\begin{array}{l}. . \\
\cdots\end{array}$ & $\begin{array}{l}\ldots \\
\cdots\end{array}$ & $\begin{array}{r}194 \\
35 \\
22\end{array}$ & $\begin{array}{l}6 \cdot 3-30 \cdot 4 \\
9 \cdot 0-29 \cdot 5 \\
9 \cdot 0-26 \cdot 9\end{array}$ & $\begin{array}{l}17 \cdot 63 \\
23 \cdot 80 \\
17 \cdot 81\end{array}$ & $\begin{array}{r}67(35) \\
5(14) \\
7(32)\end{array}$ & $\begin{array}{l}48 \cdot 3-139 \cdot 6 \\
48 \cdot 3-99 \cdot 3 \\
67 \cdot 1-127 \cdot 1\end{array}$ & $\begin{array}{l}82 \cdot 34 \\
72 \cdot 31 \\
91 \cdot 11\end{array}$ & $\begin{array}{l}53(27) \\
3(9) \\
10(45)\end{array}$ \\
\hline
\end{tabular}

Conversion: SI to Traditional Units-1 $\mu \mathrm{mol} / 1 \approx 5.6 \mu \mathrm{g} / 100 \mathrm{ml}$. 
leading to less cell breakdown and more effective erythropoiesis. If so, an increase in normal erythropoiesis might lead to a greater mobilization of available iron, and this, together with the fetal demands, might lead to a negative iron balance and a state of iron deficiency in the absence of iron supplements.

Early iron deficiency may be difficult to diagnose. The value of measuring serum iron levels is limited when anaemia is minimal or iron deficiency is incipient. The T.I.B.C. usually increases with depletion of iron stores, but it also normally increases in pregnancy and, therefore, a rising level may be difficult to interpret. Absent iron stores are generally accepted as a feature of iron deficiency. The absence of iron stores in itself may not be of great importance and an increased ingestion or absorption of food iron may be enough to satisfy iron requirements during a period of greater demand, ${ }^{10}$ such as pregnancy. The number of sideroblasts in a bone marrow film is probably a more accurate index and sideroblast counts of less than $10 \%$ indicate iron deficient erythropoiesis. Of the 22 patients in whom bone marrow examinations were done 21 showed this feature. This finding apparently contradicts those of Schuman et al. ${ }^{9}$ but in most of their patients bone marrow examination was carried out before the 28th week of pregnancy and they make the point that their limited data on bone marrow haemosiderin after the 32nd week also suggested a diminution of iron stores during pregnancy. Iron absorption is not increased in patients with $\beta$-thalassaemia trait, ${ }^{11}$ and Pakes et al. ${ }^{12}$ emphasized that these patients possess the same increased requirements for iron during pregnancy as do other women without this defect.

The serum folate and $\mathrm{B}_{12}$ levels were all normal except in one patient, who had a low serum folate and showed mild megalo- blastic change on bone marrow examination. These findings imply that these patients tend to remain in positive balance for vitamin $B_{12}$ and folic acid, but they do not exclude increased demands.

Hence, iron deficiency seems to be common in pregnant women with $\beta$-thalassaemia trait, and these patients should be given oral iron and physiological doses of folic acid throughout pregnancy, as are other women without this defect.

We thank the consultant obstetricians, North Middlesex Hospital, for help in studying these patients. We thank Miss C. Hollywell and Miss S. Fairhurst for expert technical help.

\footnotetext{
References

${ }^{1}$ Fleming, A. F., and Lynch, W., Fournal of Obstetrics and Gynaecology of the British Commonwealth, 1969, 76, 451.

${ }^{2}$ Wasi, P., Disthasongchan, P., and Na-Nakorn, S., Fournal of Laboratory and Clinical Medicine, 1968, 71, 85.

3 Dacie, J. V., and Lewis, S. M., Practical Haematology, 4th edn. London, Churchill, 1968.

4 Marengo-Lowe, A. J., Fournal of Clinical Pathology, 1965, 18, 790.

5 Singer, K., Chernoff, A. I., and Singer, L., Blood, 1951, 6, 413.

6 England, J. M., and Fraser, P. M., Lancet, 1973, 1, 449.

7 Goldberg, M. A., and Schwartz, S. O., Blood, 1954, 9, 648.

${ }^{8}$ Hegde, U. M., and Khunda, S., Fournal of Obstetrics and Gynaecology of the British Commonwealth, 1974, 81, 136.

${ }^{9}$ Schuman, J. E., et al., British Fournal of Haematology, 1973, 25, 249.

10 Isager, H., Scandinavian fournal of Haematology, 1974, no. 21 (Suppl.), p. 9 .

11 Shahid, M. J., and Haydar, N. A., British fournal of Haematology, 1967, 13, 713.

12 Pakes, J. B., Copperberg, A. A., and Gelfand, M. M., American fournal of Obstetrics and Gynecology, 1970, 108, 1217.
}

\title{
Evaluation of Creatinine Phosphokinase in Screening Patients for Malignant Hyperpyrexia
}

\author{
F. RICHARD ELLIS, I. M. C. CLARKE， MARGARET MODGILL， S. CURRIE, \\ D. G. F. HARRIMAN
}

British Medical fournal, 1975, 3, 511-513

\section{Summary}

Evidence is presented that serum creatinine phosphokinase (CPK) activity is of no direct value in screening patients for susceptibility to malignant hyperpyrexia and does not correlate with halothane-induced muscle contracture or the presence of myopathy. Widely differing CPK values were found at different times in the same people. In most "malignant hyperpyrexia" families the susceptible patients had either normal or inconsistently raised CPK values.

\footnotetext{
Malignant Hyperpyrexia Investigation Unit, University of Leeds, Leeds LS2 9LN

F. RICHARD ELLIS, PH.D., F.F.A. R.C.S., Senior Lecturer in Anaesthesia I. M. C. CLARKE, M.B., F.F.A. R.C.s., Research Fellow

MARGARET MODGILL, M.B., F.F.A. R.C.S., Senior Registrar

S. CURRIE, M.D., M.R.C.P., Consultant Neurologist

D. G. F. HARRIMAN, M.D., F.R.C.S., Senior Lecturer in Neuropathology
}

\section{Introduction}

The syndrome of malignant hyperpyrexia under anaesthesia, characterized by a rapid rise of body temperature (greater than $2{ }^{\circ} \mathrm{C}$ per hour), acidosis, hyperkalaemia, and usually muscle rigidity, carries a $60-70 \%$ mortality. ${ }^{1}$ The condition is inherited as a Mendelian dominant and so screening all members of an indexed family before anaesthesia is mandatory.

The association of myopathy with malignant hyperpyrexia ${ }^{2}{ }^{3}$ led to the suggestion that serum creatinine phosphokinase (CPK) levels may be consistently raised in susceptible patients. $\mathrm{CPK}$ is now commonly used to indicate susceptibility to malignant hyperpyrexia in relatives and yet some susceptible patients have normal CPK levels. ${ }^{4}$

Muscle from susceptible patients was found to develop contracture in vitro when exposed to certain known trigger agents including halothane. ${ }^{5}$ The same muscle tissue when investigated neuropathologically was also found to have structural abnormalities consistent with myopathy. ${ }^{3}$ The discovery of these abnormalities enabled us to offer a screening test for malignant hyperpyrexia using muscle biopsy. When a family is investigated the indexed patient is studied first because there are other unrelated causes of hyperpyrexia under anaesthesia which can mimic malignant hyperpyrexia. So far $10 \%$ of the indexed patients referred to us for investigation have been found to have normal muscle, and other causes of the hyperpyrexia have been 